Jurnal Teknologi Informasi dan Komunikasi, ISSN : 2087-0868, Volume 12, Nomor 1, September 2021, Student's Major Concentration Selection System Using Web-Based Profile Matching.

\title{
STUDENT'S MAJOR CONCENTRATION SELECTION SYSTEM USING WEB- BASED PROFILE MATCHING
}

\author{
Taufiq Ismail $^{1 *}$, Sri Winiarti² Rifki Pambudi $^{3}$ \\ 1,2,3 Department of Informatics Engineering, Universitas Ahmad Dahlan, Yogyakarta, Indonesia \\ ${ }^{1}$ taufiq@ tif.uad.ac.id
}

\begin{abstract}
Abstrak
Penelitian ini mengusulkan tentang sistem pendukung keputusan pemilihan bidang minat mahasiswa dibuat untuk membantu menyelesaikan masalah mahasiswa dalam menentukan kepeminatannya dalam bidang informatika. Metode Profile Matching dipilih karena mampu menyeleksi bidang minat yang sesuai dengan bobot kriteria yang dimiliki oleh mahasiswa. Implementasi web sistem pendukung keputusan ini menggunakan bahasa pemrograman HTML, PHP murni dan menggunakan Database MySQL. Untuk membuat tampilan web yang lebih menarik, digunakan boostrap dan javascript yang nantinya semua data aplikasi disimpan di web server penyedia hosting. Pengujian aplikasi oleh responden 10 mahasiswa dengan usability testing menggunakan Standardized Universal Percentile RankQuestionnare (SUPR-Q) untuk user dan admin serta pengujian menggunakan User Acceptance Test (UAT). Kesimpulan akhir didapatkan kesesuaian antara bidang minat yang dipilih oleh mahasiswa dengan hasil yang direkomendasikan oleh sistem dengan persentase sebesar $70 \%$.
\end{abstract}

Kata kunci : Bidang Minat, Profile Matching, Rangking

\begin{abstract}
College students often select their major concentration area wrongly due to thoughtless considerations such as following their close classmates' choice. This may cause losses in time, effort, cost, and also mental energy. The research proposes a decision support system for selecting students' major concentration areas to solve students' problems in determining their study interest in informatics engineering. Profile Matching Method was chosen since it can sort out suitable study interest with students' criteria weight. The web-based decision support system was implemented using HTML, pure PHP programming languages with MySQL as its database. Boostrap and Javascript were added to enhance the web display; all application data will be saved in the hosting provider's web server. The application testing was done to 10 students as respondents in usability testing using Standardized Universal Percentile RankQuestionnaire (SUPR-Q) for users and admins and User Acceptance Test (UAT). The conclusion was 70\% compatibility of the students' major concentration area and the system's recommendation.
\end{abstract}

Keywords: Major Concentration, Profile Matching, Ranking

\section{Introduction}

The study program of Informatics Engineering of Industrial Technology Faculty in Universitas Ahmad Dahlan has five major concentration areas that can be selected by students during the fifth semester. The major concentration areas are Information System, Web, Mobile, Multimedia, and Intelligent Systems. The selected major concentration area will be the students' discipline, which must be taken until the college study ends.

College staffs have provided information about the major concentration. However, this information is limited to the students' obligation to select concentration during the beginning of the fifth semester. This information is incomplete, plus the students are not active enough to find information about their study interest, causing potential mistakes in selecting their major concentration.
Based on a survey conducted on 30 students who entered college in 2014-2015, 23\% of respondents stated their major concentration selection was only based on following other students or following friends. Meanwhile, $10 \%$ of the respondents did not consult with academic supervisors before selecting their major concentration. The rest of the respondents have already considered and decided on their major concentration area. Therefore, $33 \%$ of students have the potential to make the wrong choice of major concentration area.

Although students can change to another major concentration area at the next semester, they suffer losses in time, mental energy, money; they have to take previous course sessions. Some courses only available in odd semesters; they are unavailable during even semesters. Therefore, students can only take courses that are available in a suitable semester. It may result in the lateness of graduation. 
Jurnal Teknologi Informasi dan Komunikasi, ISSN : 2087-0868, Volume 12, Nomor 1, September 2021, Student's Major Concentration Selection System Using Web-Based Profile Matching.

Some students choose their major concentration based on their actual abilities and interests. When these interests and abilities are considered, a problem may arise when their abilities do not match the interest. It happens with $33 \%$ of respondents. This problem can be avoided by doing a consultation with the academic supervisor or the trustee lecturer. However, what happened in the field was not as expected; opportunities for consulting with academic supervisors had not been appropriately and optimally utilized.

The research proposes a decision support system that recommends a suitable major concentration area with students' abilities and interests. A method used in the system is Profile Matching Method, a decision-making method with assumptions that there is an ideal predictor variable level that must be met by careful consideration subjects, not a minimum level that must be met or passed (Sitanggang \& Sibagariang, 2019).

The selection of major concentration has several criteria in decision making; this study proposes to build a decision support system for selecting the fields of interest of Informatics Engineering students using the website-based profile matching method. The system built is a websitebased system with consideration because it is easy to use among students. Website-based applications can be accessed with an internet connection so that application users can easily use them anywhere and anytime (Wahyudi, 2016).

\section{Theory}

\subsection{Decision Making Support System}

A decision support system is a support system for making decisions and expanding voters' capabilities in making decisions, but not to replace their judgment. Decision support systems are interactive information systems that provide information, modeling, and data manipulation (Mufid, 2014). The system is used to aid decisionmaking in semi-structured and unstructured situations, where no one exactly knows how decisions should be made (Purwanto, 2017).

\subsection{Profile Matching Method}

Profile Matching is a decision-making mechanism by assuming that there is an ideal predictor variable level that applicants must have, not a minimum level that must be met or passed (Apriyadi \& Hansun, 2018). The competency assessment process is carried out by comparing one value profile (the value of competency needs) with several other competency value profiles to know the difference in competency needs needed. The difference from competencies is called GAP (Tri Susilo, 2018). The lesser the GAP, the bigger the weight values; the recommendation's compatibility with the desired major concentration is bigger.

The steps for getting a decision in the Profile Matching are: mapping the GAP competency, determining weights, calculating, grouping the core and secondary factors, calculating the total value, and ranking (Handayani, 2017). They will be explained in detail as follows.

\section{Mapping the GAP Competency}

GAP is the difference value between the value of each aspect or attribute in the target value. It can be obtained using the equation below

$$
G A P=\text { Value Atribut }- \text { Value Target }
$$

\section{Determining Weights}

The determination of weights to each GAP value obtained is shown in Table 1 . If a parameter difference has a value of 0 , then the weight value is maximum, which is 5. Meanwhile, if a parameter has a difference of -4 , then its weight is 1 .

Table 1. GAP Weight Values

\begin{tabular}{|c|c|c|}
\hline Difference & $\begin{array}{c}\text { Weight } \\
\text { Values }\end{array}$ & Description \\
\hline 0 & 5 & $\begin{array}{c}\text { No difference } \\
\text { (competency is suitable } \\
\text { to requirements) }\end{array}$ \\
\hline 1 & 4.5 & $\begin{array}{c}\text { Individual competency } \\
\text { is 1 level higher }\end{array}$ \\
\hline 2 & 3.5 & $\begin{array}{c}\text { Individual competency } \\
\text { is 1 level lower }\end{array}$ \\
\hline 2 & 4 & $\begin{array}{c}\text { Individual competency } \\
\text { is 2 levels higher }\end{array}$ \\
\hline 2 & 2.5 & $\begin{array}{c}\text { Individual competency } \\
\text { is 2 levels lower } \\
\text { is 3 levels higher }\end{array}$ \\
\hline 3 & 2 & $\begin{array}{c}\text { Individual competency } \\
\text { is 3 levels lower }\end{array}$ \\
\hline 4 & 1.5 & $\begin{array}{c}\text { Individual competency } \\
\text { is 4 levels higher }\end{array}$ \\
\hline 4 & 1 & $\begin{array}{c}\text { Individual competency } \\
\text { is 1 level lower }\end{array}$ \\
\hline
\end{tabular}

3. Calculating and Grouping the Core Factors

Each aspect is given a GAP value. The calculation of the core factor can be done using the following equation

$$
N C F=\frac{\sum N C(i, s, p)}{\sum I C}
$$

where $N C F$ is the average score of core factors, $N C(i, s, p)$ is the total sum of core factors, and $I C$ is the number of core factors. 
4. Calculating the Secondary Factors

The secondary factor can be calculated using the below equation

$$
N S F=\frac{\sum N S(i, s, p)}{\sum I S}
$$

where $N S F$ is the average score of secondary factors, $N S(i, s, p)$ is the total sum of secondary factors, and $I S$ is the number of secondary factors.

\section{Calculating The Total Value}

The percentage of predicted core and secondary factors affect each criterion based on the following equation

$$
\begin{aligned}
N(i, s, p)=\%(x) & N C F(i, s, p) \\
+ & \%(x) \cdot N S F(i, s, p)
\end{aligned}
$$

where $N C F$ is the average score of core factors, $N S F$ is the average score of secondary factors, $N(i, s, p)$ is the total value of each aspect or criterion, and $\%(x)$ is the inputted percentage score.

\section{Ranking}

The final result of the profile matching method is the rank of candidates offered to make decisions. The decision is made using the following equation

$$
\begin{gathered}
\text { Ranking }=\%(x) . N i+\%(x) . N s \\
+\%(x) \cdot N p
\end{gathered}
$$

where $N i, N s, N p$ are the value of aspects used, and $\%(x)$ is the inputted percentage score.

\section{Methods}

\subsection{Research Object}

The object of this research is the decision support system for selecting a major concentration area of the Informatics Engineering students in Ahmad Dahlan University, with the source of information coming from the Head of the Study Program.

\subsection{Data Colletion}

The data collection was carried out by conducting interviews with the Head of the Informatics Engineering Study Program (Kaprodi) of Ahmad Dahlan University.

\subsection{System Design}

The design of the system consists of a use case diagram, activity diagram, and flowchart. The process design used a Use Case Diagram, a diagram describing actors' interactions with the built system and its functionality. Activity Diagram depicts the system flow activities in the built system, even describes how each flow starts. A flowchart is a graphic representation of the stages that must be followed in solving a problem consisting of a set of symbols in the form of a flat shape; each symbol represents a specific activity [8]

\subsection{System Implementation}

The web implementation of this decision support system used HTML and PHP as programming languages, and a database was created using MySQL. Boostrap and javascript were used to create a more attractive web appearance. Later, all application data would be stored on the web server of the hosting provider.

\subsection{System Evaluation}

Methods used for system evaluation are Usability Test and User Acceptance Test. Usability Test was done to evaluate the system used by the users. The user tries the system, and the observer will observe, listen, and record qualitative and quantitative data to determine the user's satisfaction. User Acceptance Test is the user's evaluation to ensure functions on the system are running well and suitable to the user's needs.

\section{Conclusions}

\subsection{System Design Result}

The calculation process activity diagram describes the activity flow in the Profile Matching method's calculation process [10] and can be shown in Figure 2. There are three parts to the diagram: students, database, and system. There is a main menu display in the system part; it contains the parameter data form that must be filled in, the parameter calculation process, and the display of decisions in major concentration area results. In the database section, there are parameter data requests and result posts. There are two sub-sections in the student section: selecting the profile matching menu and inputting the parameter form. The process of activity flow starts from the system displaying the main menu; then, students choose the profile matching menu so that the database will ask for parameter data requests. The system then displays the parameter data form that must be filled in, and the students will input the parameter value form. After that, the system will calculate the parameter value, and decision results in the major concentration area will be displayed. The results will then finally be stored in the database. 
Jurnal Teknologi Informasi dan Komunikasi, ISSN : 2087-0868, Volume 12, Nomor 1, September 2021, Student's Major Concentration Selection System Using Web-Based Profile Matching.

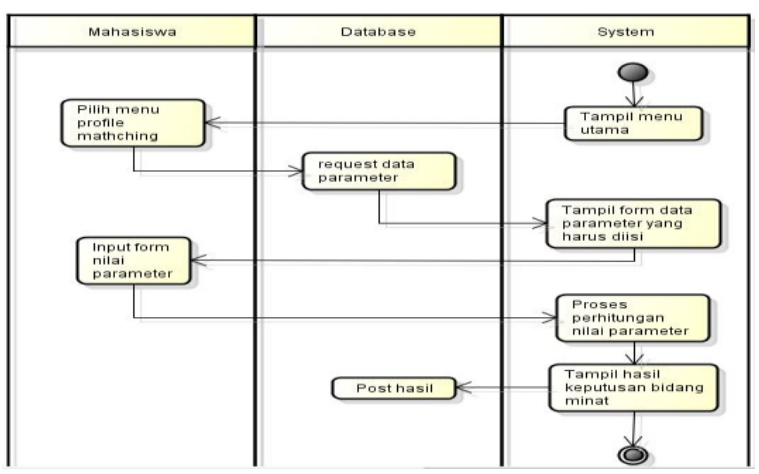

Fig 1. The Calculation Process Activity Diagram

The steps are used to describe the processes that occur in decision support system applications. A flowchart is used to describe the flow and sequence of activities in the system. The decision flow for the profile matching method can be seen in Figure 3. After the system is run, the input variables are the value of each attribute and the target value, then proceed with the GAP competency mapping process. Furthermore, the weighted value is calculated for each GAP value. GAP is the difference between the value of the attribute (student course value) and the target value (the reference course's value). Next, the calculation and grouping of the core factor value and the secondary core factor value are done. The next stage is the calculation of the total value and ranking. After that, the output or system output ranks the major concentration areas according to the calculation process.

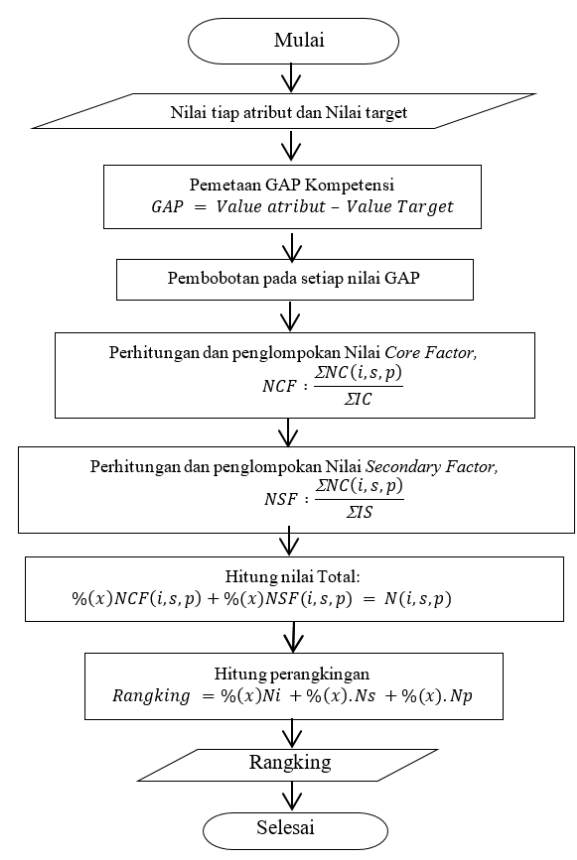

Fig 2. The flow of the decision-making

\subsection{System Implementation Results}

In this process, students are required to fill in all parameter value forms for the calculation process carried out by the system. The input process for parameter values is shown in Figure 4. Several menus are on display: the dashboard menu, knowledge menu, history menu, and profile matching menu. In the profile matching section, there is a data input menu for prerequisite courses. In that section, students are asked to enter the value of the prerequisite course. After students enter the prerequisite course scores, the system will calculate the major concentration area's value based on the prerequisite course's value.

After performing the calculation process, the final results are ranked from the highest to the lowest ranks, and the highest-ranking results are the system's decisions. The implementation of the Profile Matching calculation process is shown in Figure 5. There are five major concentration areas with the final score ranked. From these results, it can be seen that the final score for the major concentration area in multimedia gets the highest score, so the student is expected to choose multimedia as his/her major concentration area.

Another result observed in Figure 5 is that students can also take the second-ranked major concentration area if students feel that the field is more suitable for their abilities. Students are expected not to take the major concentration area in the last rank because they are not suitable for taking the major concentration area in the last rank based on the system calculation.

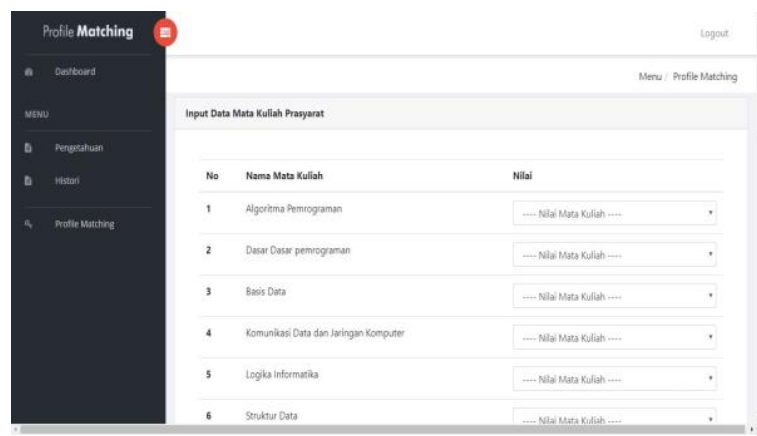

Fig 3. The Implementation of the Parameter Input Process

The application's evaluation with the usability testing method used the Standardized Universal Percentile Rank-Questionnaire (SUPR-Q) calculation and obtained $79.17 \%$ for user's score from 10 evaluation cases and categorized in C-grade scale (Good). The SUPR-Q calculation for admin is $81.81 \%$, and then it can be categorized into a Bgrade scale (Good).

Evaluation using the User Acceptance Test method was carried out to 10 users to ensure that the system's functions are running properly and following user needs. The evaluation results in an 
Jurnal Teknologi Informasi dan Komunikasi, ISSN : 2087-0868, Volume 12, Nomor 1, September 2021, Student's Major Concentration Selection System Using Web-Based Profile Matching.

average percentage of $82.25 \%$. In detail, the results of the percentage assessment for each item are as follows:

1. Attractive display $(70 \%)$

2. System menus are easy to be understood $(84 \%)$

3. System menus function well $(88 \%)$

4. Histories can help in evaluating students' skills and abilities (68\%)

5. Knowledge can help in understanding information of major concentration area $(76 \%)$

6. The system has been following the need to determine the major concentration area $(92 \%)$

7. The system can help to decide the major concentration area $(92 \%)$

8. The decision support system is considered quite good $(88 \%)$

\section{Conclusions}

The research made a web-based decision support system using a Profile Matching Method that helps students choose their major concentration area. The application was evaluated using the Usability Testing method with the Standardized Universal Percentile Rank-Questionnaire (SUPR-Q), which obtained scores for users as $79.17 \%$ and $81.81 \%$ for admin. Meanwhile, evaluation using the User Acceptance Test Method has been done to 10 respondents/users to ensure the system's functions are running well. The evaluation resulted in an $82.25 \%$ average percentage score.

Based on evaluation results from 10 students, the compatibility of the major concentration area chosen by the students with the recommendation result from the decision support system is $70 \%$. The mismatch occurred not because of the decision support system's calculation problem but due to the students' wishes. Possible future work is developing the proposed decision support system as a mobilebased system to make easier access for students. Also, a development in the access could be made so that academic supervisors can access the system to observe the students' academic developments.

\section{References:}

Apriyadi, M., \& Hansun, S. (2018). Sistem Pendukung Keputusan Penerima Beasiswa
UMN dengan Profile Matching. Jurnal

ULTIMATICS, 10(1), 1-6. https://doi.org/10.31937/ti.v10i1.702

Hakim, Z., Sudiarjo, A., \& Efrida, R. (2017). Rancangan Sistem Penunjang Keputusan Pengangkatan Karyawan Tetap Dengan Metode Profile Matching di PT. Lotte Packaging. Jurnal Sisfotek Global, 7(2), 9399. https://doi.org/10.38101/SISFOTEK.V7I2.158

Handayani, R. I. (2017). Sistem Pendukung Keputusan Pemilihan Karyawan Berprestasi dengan Metode Profile Matching Pada PT. Sarana Inti Persada (SIP). Jurnal Pilar Nusa Mandiri, 13(1), 28-34. https://doi.org/10.33480/PILAR.V13I1.11

Mufid, A. (2014). Sistem Pendukung Keputusan Penilaian Proposal Kegiatan PNPM MPd Menggunakan Metode Profile Matching dan Analytic Hierarchy Process (AHP). Jurnal Sistem Informasi Bisnis, 4(1), 30. https://doi.org/10.21456/vol4iss1pp40-47

Purwanto, H. (2017). Penerapan Metode Profile Matching Dalam Sistem Pendukung Keputusan Penilaian Kinerja Karyawan Pada PT. Hyundai Mobil Indonesia Cabang Kalimalang. Jurnal Techno Nusa Mandiri, 14(1), 15-20. https://doi.org/10.33480/TECHNO.V14I1.179

Sitanggang, R., \& Sibagariang, S. (2019). Model Pengambilan Keputusan Dengan Teknik Metode Profile Matching. Computer Engineering, Science and System Journal, 4(1), 44 https://doi.org/10.24114/cess.v4i1.11460

Tri Susilo, A. A. (2018). Penerapan Metode Profile Matching Pada Sistem Pendukung Keputusan Pemilihan Ketua Program Studi (STUDI Kasus : Program Studi Teknik Informatika STMIK Musi Rawas). JUITA : Jurnal Informatika, 5(2), 87. https://doi.org/10.30595/juita.v5i2.1939

Wahyudi, A. D. (2016). Sistem Pendukung Keputusan Seleksi Penerimaan Staff Administrasi Menggunakan Metode Profile Matching. Jurnal Teknoinfo, 10(2), 44. https://doi.org/10.33365/jti.v10i2.13 